ISSN: 2277-3754

ISO 9001:2008 Certified

International Journal of Engineering and Innovative Technology (IJEIT)

Volume 10, Issue 12, June 2021

\title{
Water Supply-Demand and Transferring Compensation Fee
}

\author{
LUO Ching-Ruey (Edward) \\ Associate Professor of Department of Civil Engineering, National Chi-Nan University, Taiwan
}

In this article, the focus will be on the water supply-

\begin{abstract}
Reliable water availability has been termed "water security", defined as "the availability of an acceptable quantity and quality of water for health, livelihoods, ecosystems and production, coupled with an acceptable level of water-related risks to people, environments and economies." Water is a mostly important resource for Taiwan, an island surrounded with Taiwan Strait and the Pacific Ocean. Three main utilizations of water are for livelihood, agriculture, and industry. Three properties of water are quantity, quality, and water right. Three control factors are sufficient for quantity, stable for quality, and fair for distribution. In the seriously global climate change, the conjunction uses for surface water and groundwater will be the long-term strategy, while the compensation for transferring the water volumes from agriculture to industry is a short-term purpose. In this article, the water supply-demand of Taiwan from 2010 to 2019 will be discussed and the example of 2016, a significant period, are given. Here, the calculation of compensation fee for transferring the water volumes from agricultural purpose to industrial utilization is also presented.
\end{abstract}

Index Terms-- Livelihood, agriculture, industry, quantity, quality, and water right, conjunction uses, compensation.

\section{INTRODUCTION}

Fresh water is the life-blood of the environment. There is no life without water - nothing can survive without water including human beings. Water is essential for human being to survive and develop. At the same time water is a scarce resource, sometimes the shortage is acute enough to cause crises. Both facts lead to the simple conclusion that lack of water hinders development and the right to live in dignity. Although $70 \%$ of earth is water, the growing freshwater crisis has impact on billions of people on our planet. In no other case is the link between well-being of the people and the environment so clear. To deal the water crisis requires a clearer understanding of the extent of the problem, their causes and the solutions available. There are some difficult problems of water with geo-political implications that are the subject of strong views as to causes and solutions. Without supporting either side involved in these contentious issues, we emphasize that any proposed solution must treat the environment as part of the solution, but it is not a competitor for scare water resources. Water resources and land resources are two basic and essential factors for the living of not only human being but also the animals and plants on the Earth, especially for the island of Taiwan. Recently, due to the serious of the global water shortage crisis, the keen water supply-demand policies will be needed for testing the resilience of the government. Some issues about water were discussed before ([4], [5], [6], [7], [8]

\footnotetext{
Manuscript received: 23 May 2021

Manuscript received in revised form: 21 June 2021

Manuscript accepted: 6 July 2021

Manuscript Available online: 15 July 2021
}

demand variation within the recent years, from 2010 to 2019, and the compensation fee on the economic effects in present values about water transferring from agricultural use to the need of by the industrial utilization. Taiwan has population as mean $23,000,000$ living on the area of 36,000 squarekilometers as very high population-intensity, even the amount of population is decreasing recent years. Due to the life quality progressive, the necessity on water for living also increases but the water supply has in quite sensitivities on apace and seasons, the shortage of water always the main topic of Taiwan government to face, especially during the winter to spring before the plum rain coming. Livelihood, agricultural, and industrial water are high-tech industry increasing quickly with the requirement of stable quantity and good quality from the three important demands, even the demand on agriculture decreases gradually, but the water need on supply-side. Based on the five-year rolling review, the example of 2016 is given with others presented in the variation.

\section{BASIC THEORY}

As The concept of basic water requirement (BWR) was proposed by the governments of different countries, water agencies and community organizations. The concept refers to the amount of water that an individual would need daily to fulfil their four basic domestic needs like drinking, sanitation, bathing and cooking. Potential human right issues can arise from lack of safe water. Lack of access to safe water in the vicinity of the home can affect the health. Water footprints, defined as the total volume of fresh water used for production of goods and services consumed by the individual or community, and virtual water are often used to describe the relations between water management, international trade and policies. On the other hand, virtual water is referred to the amount of water used for the production of goods or services, and is a tool for determining the movement of water through international trade. Water mainly a local issue, although it becomes a regional issue where rivers or lakes cross national boundaries. It is the virtual water that actually makes it a global issue in terms of production and consumption. Countries with water shortages can import water-intensive goods and services, while waterabundant countries can increase the economic strength by using the crisis. A warmer climate will accelerate the hydrological cycle; can alter the intensity and timing of rainfall. Warm air can hold more moisture and can increase evaporation of surface moisture, which in turn can intensify rainfall and snowfall events. So, intensity of flood will also increase. If there is deficiency of moisture in the soil, solar 
ISSN: 2277-3754

\section{ISO 9001:2008 Certified}

International Journal of Engineering and Innovative Technology (IJEIT)

Volume 10, Issue 12, June 2021

radiation will increase the temperature, which could contribute to longer and more severe droughts. In a number of studies, it has been proved that global warming and decline in rainfall may reduce net recharge and can affect groundwater levels. Decrease in winter precipitation would reduce the total seasonal precipitation being received during December-February, and can impose greater water stress. Intense rain for few days will result increased frequency of floods and the monsoon rain would be lost as direct run-off, thus can decrease the groundwater recharging potential. Increased rainfall amounts and intensities will lead to greater rates of soil erosion.

\section{THE EXAMPLE OF 2016}

Any analysis of the need for water storage requires reflection on the water cycle, since the details of processes and quantities are fundamental to understanding water issues. The general perception of the hydrological cycle is one of a single large cycle of evaporation from the oceans, precipitation on the land and discharge to the sea via surface runoff in rivers or aquifers. Heavily vegetated surfaces will have access to a large store of water in the soil, through their root zone (typically 1 to $10 \mathrm{~m}$ ), and will tend to be able to evaporate freely (with annual rates between 500 and $1500 \mathrm{~mm}$, a value controlled by the energy available from the sun). Bare soil and partially vegetated areas will evaporate freely for a few days after rainfall until the surface soil store (typically a few $10 \mathrm{~s} \mathrm{~mm}$ ) runs out. In these areas, a large proportion of the precipitation will either run off the surface or percolate through the soil to the groundwater. Groundwater currently provides the majority of water storage used in the world and is the largest store of unfrozen fresh water. It has the potential to provide water over a number of years and hence buffer water resources through both seasonal and multi-year variations and major droughts. Based on the data of Water Resources Agency, MOEA Taiwan, 2016, the information could be shown after rearranged by author as following:

\section{Growth of Population from 1975 to 2016}

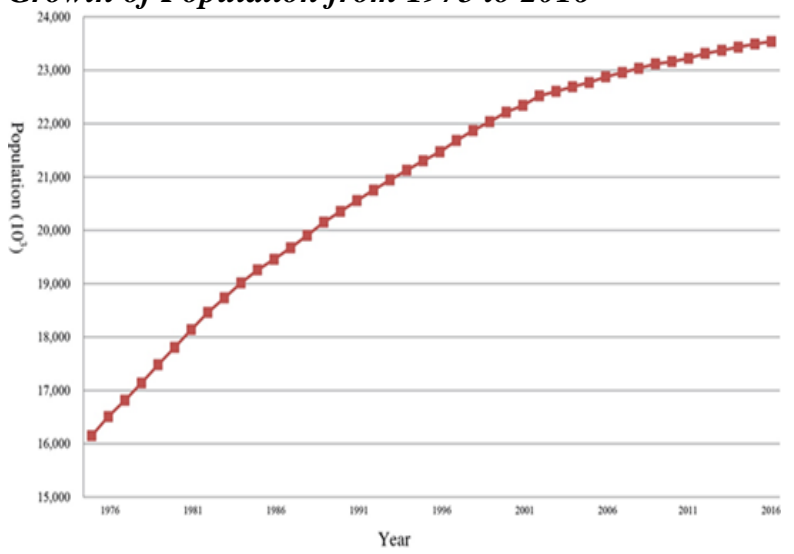

Fig.1. Growth of Taiwan's Population over Years up to 2016

The following figure is to show the water supply in Taiwan for the annually mean volume.

2. Water Distribution (Supply) in the unit of 0.1 billion cubic meters.

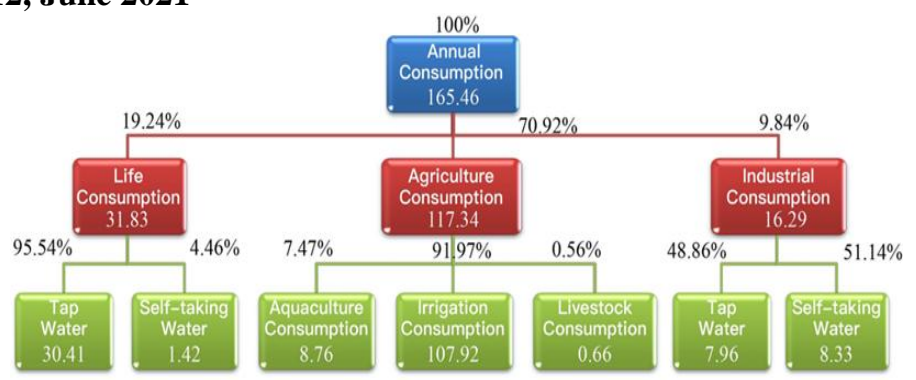

Fig.2. The water consumption of Taiwan in 2016 (in 0.1 billion Cubic meters)

3. Water Consumption (Demand) for Each Target of Taiwan from 1980 to 2016

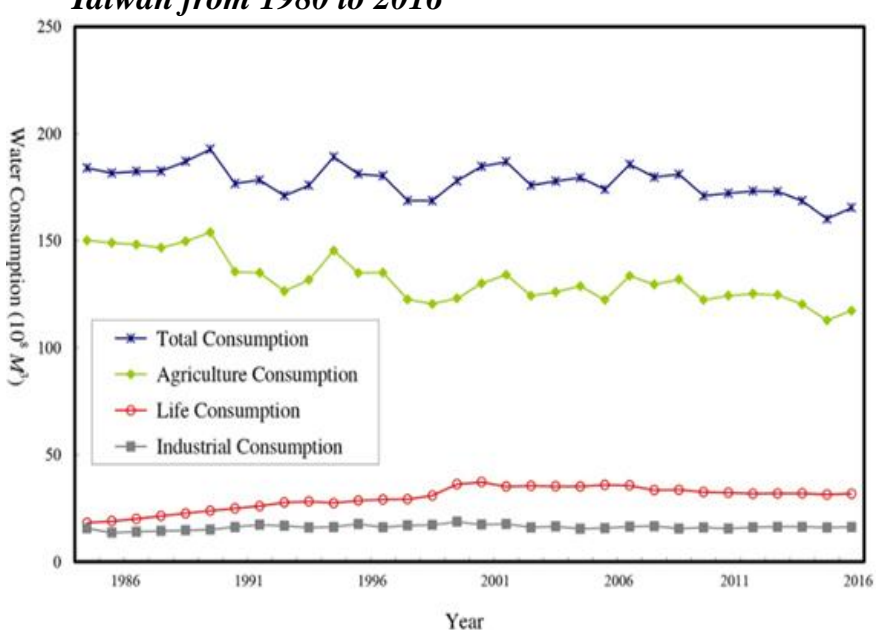

Fig.3. Water Consumption for Each Target in Taiwan over Years up to 2016

4. Livelihood water consumption (Distribution for Demand) from 1976 to 2016

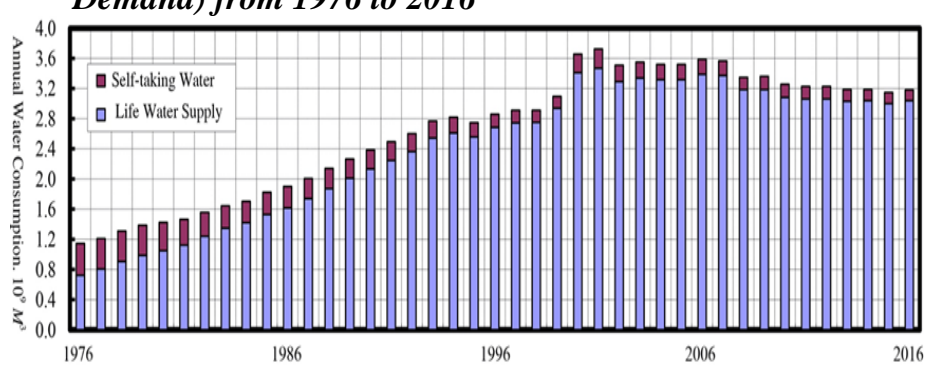

Year

Fig.4. Livelihood water consumption of Taiwan over years upto 2016

5. Tap water distribution (Consumption)from 1976 to 2016

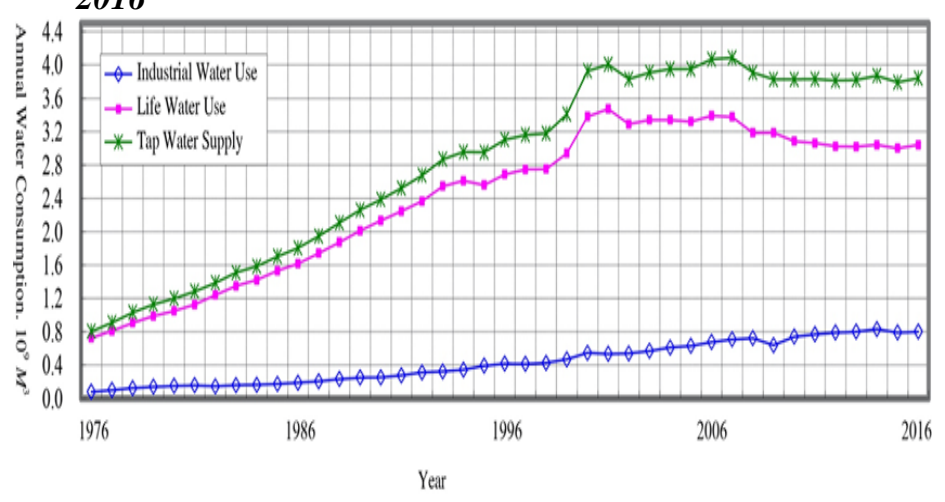

Fig.5. Tap water distribution (Supply) in Taiwan over years up to 2016 


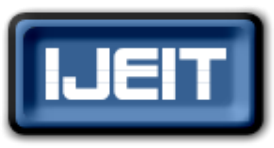

ISSN: 2277-3754

ISO 9001:2008 Certified

International Journal of Engineering and Innovative Technology (IJEIT)

Volume 10, Issue 12, June 2021

6. The water consumption in livelihood per day per 10. Industrial water consumption (Totally) from 1991 to person from 1976 to 2016

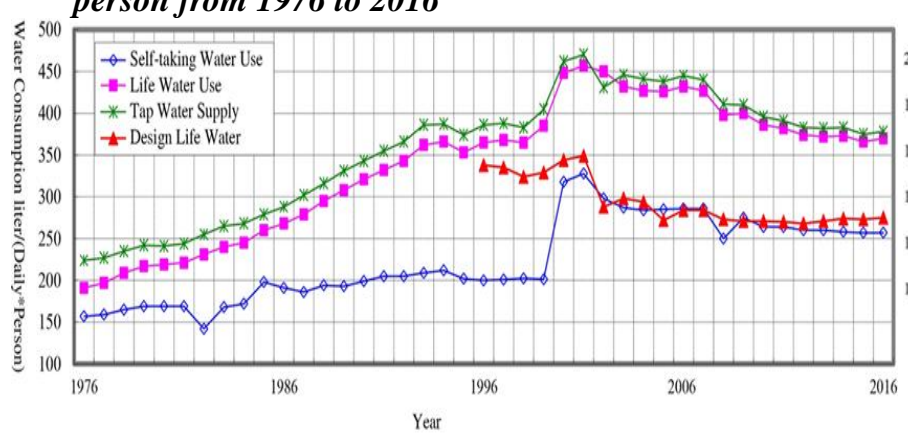

Fig.6. The livelihood water consumption in Taiwan @ day@ person over years up to 2016

7. Agricultural water consumption from 1983 to 2016

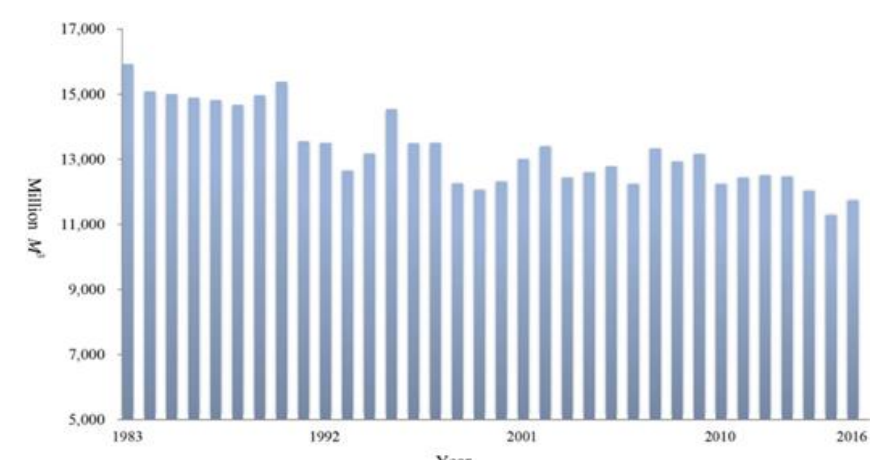

Fig.7. Agricultural water used in Taiwan over years up to 2016

8. Industrial Area (Totally) from 1991 to 2016

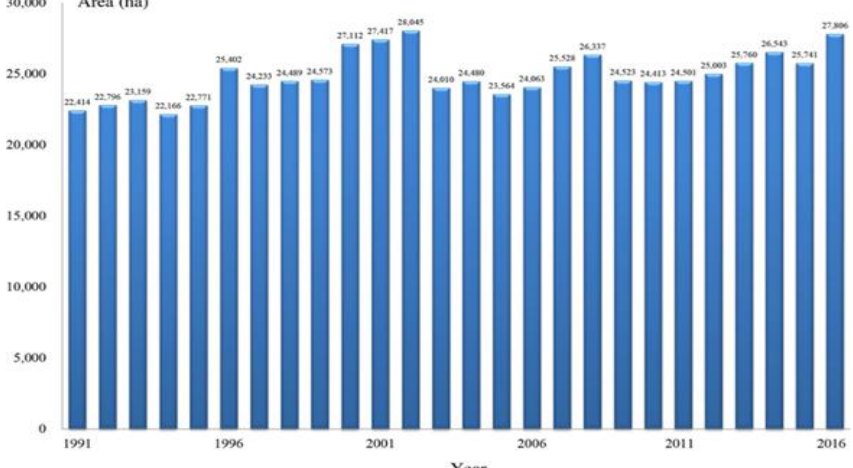

Fig.8. Total industrial area in Taiwan over years up to 2016

9. Industrial Area (Partition) from 1986 to 2016

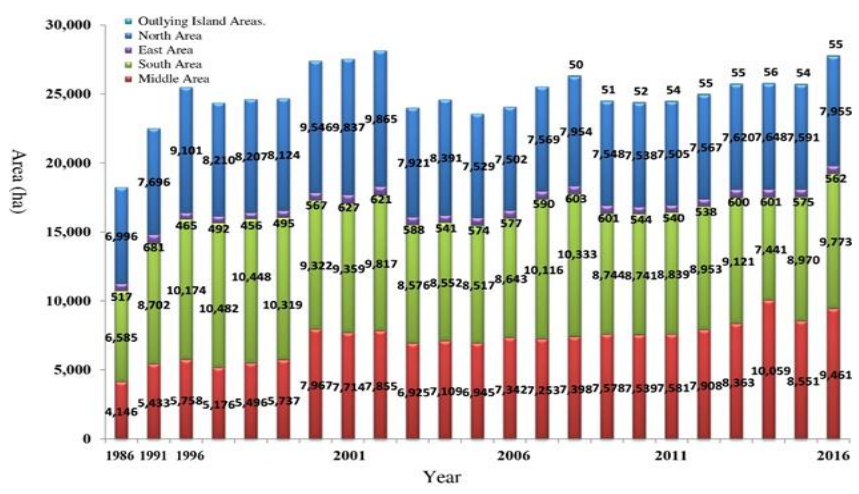

Fig. 9. Partial industrial area in Taiwan over years up to 2016
2016

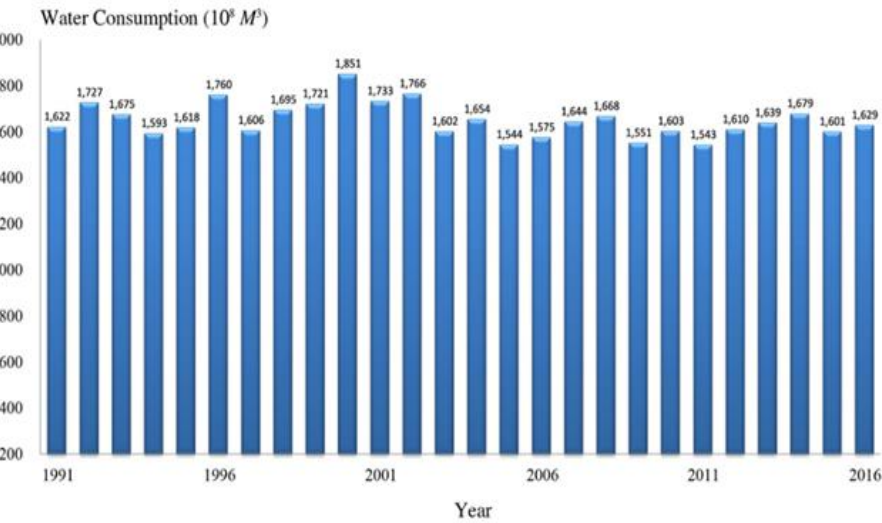

Fig.10. Total industrial water consumption in Taiwan over years up to 2016

11. Industrial water consumption (Partition) from 1986

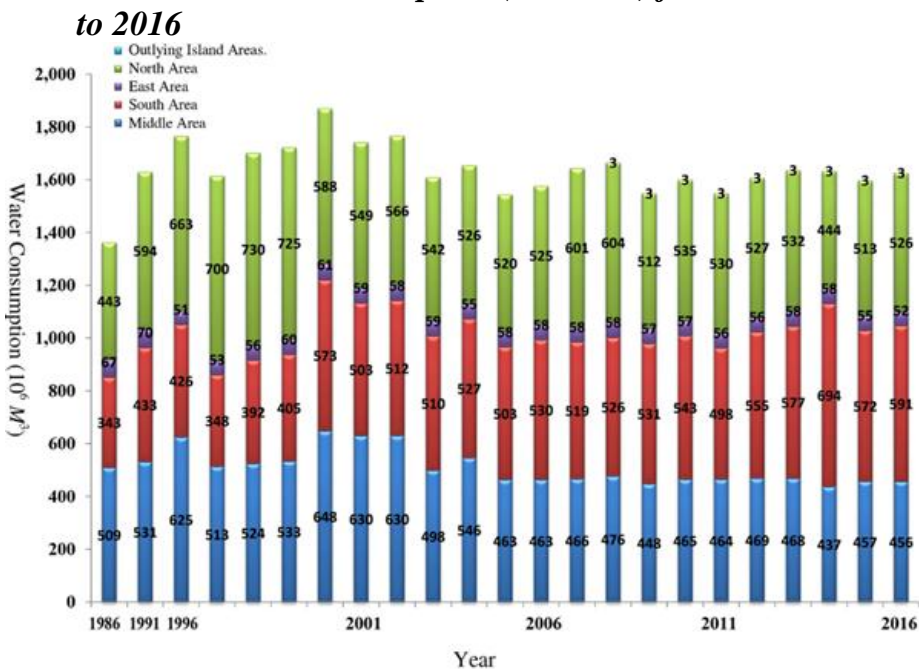

Fig. 11. Partial industrial water consumption in Taiwan over years up to 2016

\section{THE VARIATIONS}

The spatial and temporal distribution of water resources across the globe are determined largely by rainfall and evaporation, and follow factors that influence cloud formation, such as the amount of solar heating, surface temperatures, topography, and proximity to the sea and large lakes. Movements in large-scale atmospheric systems. In addition to long-term variations in climate, shorter-term fluctuations are important. The spatial and temporal nature of rainfall creates water resource variability of various types in different areas of the world. For many direct water use activities, such as domestic and industrial use, a constant rate of supply is needed all year round, although variations will occur in agriculture depending on crop growing seasons. Water storage cannot be assessed in isolation, but must be seen in the context of other issues that have significant impacts, such as population increase, changes in food security, commodity prices, climate change and influences on surface water and groundwater, sea level rise and saltwater intrusion, and land use change, on supply of water resources, demand for water and the ability to utilize storage. 
ISSN: 2277-3754

ISO 9001:2008 Certified

International Journal of Engineering and Innovative Technology (IJEIT)

Volume 10, Issue 12, June 2021

The following information, rearranged by author, are presenting for the time 2010 to 2019 with the different water concerned issues.

\section{Annual Increment Rate of Total Water Consumption}

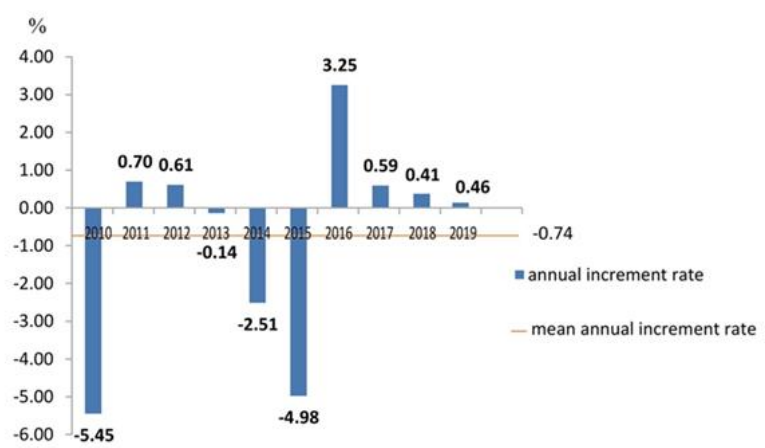

Fig.12. Annual Increment Rate of Total Water Consumption (2010 to 2019)

From the above figures, we can find that the mean annual increment rates from 2010 to 2019 are not very obvious, but the annual increment rates before 2016 are what random values.

\section{Annual Increment Rate of Livelihood Water Consumption}

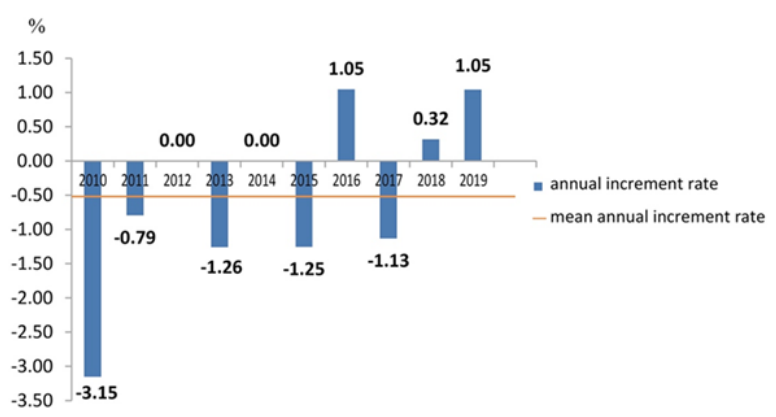

Fig.13. Annual Increment Rate of Domestic-Use Water Consumption (2010 to 2019)

From the above three figures, the trends of livelihood water consumption after 2016 is approaching stable.

3. Annual Increment Rate of Agricultural Water Consumption

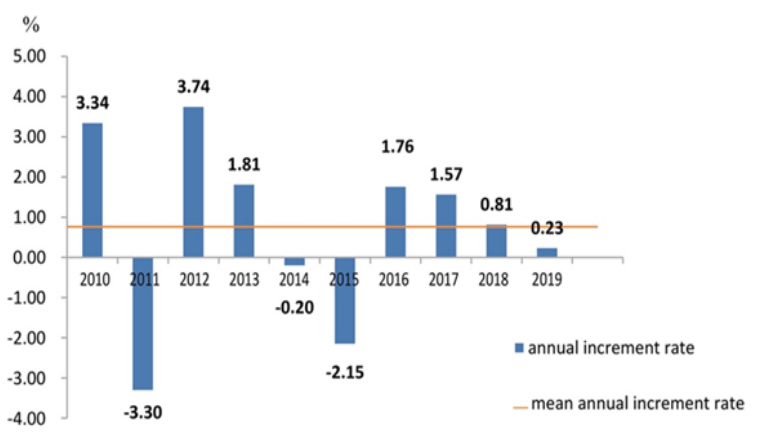

Fig.14. Annual Increment Rate of Industrial Water Consumption (2010 to 2019)

From the three figures of the industrial water consumption trends, we can find the demands on the industrial utilization are increasing.
4. Annual Increment Rate of Agricultural Water Consumption

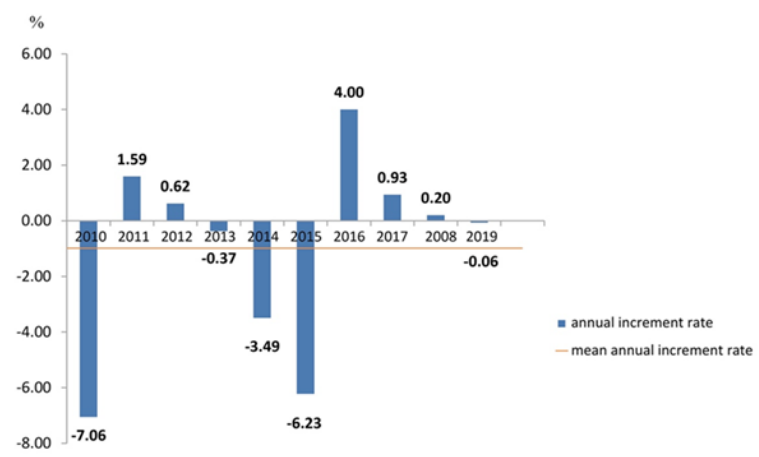

Fig.15. Annual Increment Rate of Agricultural Water Consumption (2010 to 2019)

The trends of the agricultural water consumption have a little increasing but not very obviously.

\section{V.THE COMPENSATION FEE FOR WATER TRANSFERRING}

Because water resources are becoming more and more precious, how to exert its benefits from all available water sources without causing environmental protection and social cost increase, and put forward the strategy to solve industrial water use, has become the bottleneck that must be broken under the premise of industrial development today. Access to water is clearly a wider subject than availability and many other factors including cost distance to water source, rights, authority and corruption can create water poverty (the opposite of water security) at household and community levels. The distribution of water infrastructure is inversely related to the global distribution of water insecurity risks. Many of the world's wealthiest nations also have the highest water security and investment in water storage has enabled growth where hydrological variability is high, although growth often requires ongoing non-infrastructural investment. However, direct cause-effect relationships are not always clear; wealth may enable extensive water storage, or water storage may be the source of their wealth. Industrial water includes process water, cooling water and compression water; these water characteristics are often ignored. Also because of the different types of industrial projects, therefore, there are different water quality requirements and treatment costs and the requirement of industrial water is quite varied to the one of agricultural water [6]. Water quality treatment is a cumbersome chemical treatment, not to talk about for the time being. The water quality standards required by the different processes will also go with more appropriate and water quality combined with the original treatment of water, of course, directly from the reservoir, and then through special channels or pipelines to the industrial zone, which is ideal, because such an industrial category only need to deal with water quality has reached the required standards.

Water can be obtained from the river directly with some taking-water constructions, digging wells for groundwater, constructing rainwater catchment for the collection systems 


\section{ISSN: 2277-3754 \\ ISO 9001:2008 Certified \\ International Journal of Engineering and Innovative Technology (IJEIT) \\ Volume 10, Issue 12, June 2021}

[4], or desalination. Even the reservoirs and well construction are mainly engineering solutions, the influences on environments are serious, and some social struggle will always happen and this is named social cost, which is unpredictable. Therefore, to take the primary water from the existing reservoirs and water transferring systems could be the strategy [5]. Water-demand management is highly desirable and, in many cases, is a priority for water managers but, though its impact may be significant, its potential is still limited over the medium-term. Transfers of water to uses of higher economic value are occurring and will undoubtedly continue. Rather than minimizing or concealing their effect, planners should acknowledge that highly committed water systems will have to cope with growing uncertainty and fluctuations in supply: contingency planning should allow for short-term transfers, with compensation to those surrendering supplies planned in advance so as to avoid upheavals and water crises. Such transfers neither preclude nor require water markets. However, markets have prerequisites that are unlikely to be met in most countries and the alternative of transfers administered and designed through processes of negotiation is likely to predominate. More generally, better access to hydrological data, improved control over hydraulic regulation, multi-stakeholder platforms or other arenas for achieving common goals, and patterns of governance which include empowerment of marginalized social/ethnic groups and representation of all interested parties in allocation and decision making, have the potential for ensuring fairer and smoother reallocation of water.

This section provides a typology of temporary transfers typically occurring during a drought on how water is transferred in practice from agricultural to industrial uses. If the source is large, the impact on irrigation users may diffuse and be unidentifiable. If the transfer is a large portion of the source (often the case during droughts), then temporary allocation directly affects on a known group of farmers who may have to be compensated for their (temporary) loss. Once the emergency is over, allocations revert to the original pattern, always with the possibility that drought will return sometime in the future. Transfers can be distinguished according to the share of the source of origin that is diverted. On the consideration of transfer mechanisms utilized in their implementation, the first type of transfers occurs through the transfer of formal rights to the use of water. These are typified by practices in developed countries. Negotiations can include financial compensations and/or efforts by the agricultural sectors to reduce its losses or its consumption. When formal administrative decisions to transfer water are taken unilaterally, they merge imperceptibly into informal transfers by stealth. This may occur because of investment decisions or management decisions, or development decisions. The charge of industrial water on compensation by transferring from agriculture, not including the water quality treatment, contains primary water cost [6] with the consideration of storage scales and the effects of constructed timing, the rental fee of transferring system, the fee of management, the labor cost, and the government fallow grant due to the farming fallowing. The interesting rate, $\mathrm{r} 1$ $=3 \%$, and the exchange rate, $r 2=2 \%$, will be considered for the calculation on the present value transfers.

For example, the primary water cost could be obtained by the formula (1) [6] :

$\ln \mathrm{C} 0=a+b \ln \mathrm{X}+\mathrm{c} \ln (\mathrm{T}-1911)$.

With $\mathrm{a}=-15.0211, \mathrm{~b}=0.8415$, and $\mathrm{c}=4.00297$, and $\mathrm{R}$ square $=$ 0.8114 , and $\mathrm{X}$ in million Tons, $\mathrm{T}$ in $\mathrm{A}$. D. year.

Transferring the annually mean cost of the reservoirs in Taiwan, 4.64 NT dollars in 1991 is the value. While the tap water fee $\mathrm{C} 1$ [7] also could be gained by:

$\ln C 1=1.727052+0.9090841 \ln \mathrm{X}$

The definition of $X$ as the same as the above mentioned, and with $\mathrm{R}$ square $=0.926876$

The mean tap water fee is 5.00 NT dollars in 1991, and the difference between 5.00 and 4.64 valued 0.36 is the management fee of Taiwan Tap Water Company.

The rental fee for transferring water (Agriculture Irrigation Association) [1] could be calculated based on the formula from agriculture irrigation associations, which now belong to Agricultural Committee of the Executive Council, as following:

(Annual transferring water volume $) \times($ Discount rate)+Accumulate fee $=$ The payments.

Here, for example, the annual transferring water volume is $30,000,000$ Tons, and the discount rate, 0.55, with the accumulate fee 637, 550 NT dollars in 1991, there, the rental fee per cubic meter water will be 0.57 NT dollars. The transferring management fee is 0.27 NT dollars. The lost for farming fallow (Department of Agriculture and Forestry, Taiwan Province) [2] is given as 6.59 NT dollars.

The net fee for transferring water from agriculture to industry is summed as:

$4.64+0.57+0.27+6.59=12.07$

The total transferring fee can be calculated by $12.07 \div(1-$ $0.071)=13.00$, here the value of 0.071 is the rate of water deployment by reservoir management bureau. From the viewpoint of present-value, the payment from the industrial unit is:

(The summed fee in 1991) $\times$ (compound interest rate of interest $) \times$ (compound interest rate of exchange), with interesting rate, $\mathrm{r} 1=3 \%$, and the exchange rate, $\mathrm{r} 2=2 \%$, and $n=$ the calculation period $=2021-1991=30$, therefore, the compensation fee in 2021 is 57.16 NT dollars.

\section{DISCUSSION AND CONCLUSIONS}

In this article, we present the water resources on supplydemand situation of Taiwan from 2010 to 2019 with the example of 2016 and the variations for each water demands. The compensation fee for moving water from agriculture to industry is clearly calculated even the treatment of water quality for each requirement of industrial purposes is neglected, and the fee expressed by annual mean while the characteristics of water supply in not only in space but also in seasons are also not mentioned. From the calculation steps, the water resources in precious and irreversible, the price of this resource is only going to get more and more expensive, 


\section{ISSN: 2277-3754 \\ ISO 9001:2008 Certified \\ International Journal of Engineering and Innovative Technology (IJEIT)}

Volume 10, Issue 12, June 2021

and it is getting harder and harder to control because of the global climate change. Humans must respect water resources and change their water use habits so that they can survive the growing shortage of water resources. Based on the trends of desalination, the constructions of desalination [8] plants will be springing established but the energy resources and the high concentrations of saline discharge become new problems, especially in Taiwan. Rainwater can be used as the alternative water sources to substitute the miscellaneous water in life which occupying about $35 \%$ of the daily livelihood water. In industrial parks, the roofs ([9]) of the plant can be used to collect solar energy and rainwater, the former can be treated the energy sources for air-conditioned use and the latter as the cooling water. The green lands in the industrial parks can be dig as the rainwater storage space with the aerated equipment.

Groundwater is the largest global store of freshwater on the planet that is not frozen. Many estimates have been made, but the available fresh groundwater globally still need to make sure even it may a fluctuation. Estimates of annual recharge to aquifers forming of global fresh groundwater storage is needed to research soon. Groundwater provides a buffer to climate variability, smoothing out periods of intense precipitation and drought. This effect can be seen on an annual scale, such as recharge in temperate or seasonal monsoon climates, as well as over extended periods of several years.

Groundwater discharge maintains river's flow during seasonal dry periods. In its natural state, the water cycle finds a balance, not necessarily on an annual basis, where, on average, groundwater discharge equates to groundwater recharge. This balance is disturbed by groundwater abstraction resulting in falls in groundwater levels and consequent reductions in base-flow to rivers. Water resources can be sustainably managed to minimize impacts on environmental flows by using delays in the system and by creating additional storage in aquifers. Furthermore, the conjunction of surface-ground water must be the main topic in this 21 st century. Climate change is expected to have considerable impacts on water resources, which, in turn, can lead to social instability and conflict, often followed by displacement of people and changes in occupancy and migration patterns. The production losses due to climate change may drastically increase the problem of poverty, food insecurity and malnutrition in several developing countries in Asia. Sustainable development has become part of all climate change policy discussions at the global level. Environmental conservation for sustainability of natural resources is not a luxury but a necessity when considering long-term economic growth and development, particularly in the least developed countries. Linking the concept of sustainable development to climate change provides an opportunity to explore long-term societal responses to global environmental change, which, in turn, can conserve human rights as a whole. The administrations are consciously overlooking the complexities of the water management systems that are deeply integrated in the social, political and economic structures. On the other hand, water has become big business for global corporations. It has limitless markets in the changing scenario of growing water demand and water scarcity. Water privatization will invariably increase the price of this common property resource because there are hidden costs involved in water collection, purification, distribution, and the spatio-temporal difference price, a very sensitive topic. The corporations will recover their costs by exploiting the consumers. It has been argued that privatization will help to reduce unsustainable water use and will promote water conservation. However, the market dynamics will inevitably affect the economically weaker class of the society who cannot afford the increased water tariffs. The meaningful implementation of sustainable development can now be further advanced to help link social development and human rights aspects of sustainable development with the environment, as well as ensuring economic well-being through the benefits that adequate supplies of water can provide.

\section{REFERENCES}

[1] Luo C.R., "Benefits of Rainwater Utilization- The Applications on Flood Mitigation, Snipe Design", Resources and Environment 2012, 2(5): pp: 180-184.

[2] Luo C.R., "Water Supply-Demand: Quantity, Quality and Price of the Water Conjunctive Use", International Journal of Hydrology, Volume 1 Issue 6, 2017, pp: 199-200.

[3] Luo C. R. and Liu C. W., "Agricultural water demand with its cost". International Journal of Hydrology, Volume 2 Issue 6, 2018, pp: 709-711.

[4] Luo C. R.,"The characteristics and function of the fluvial ecosystem - a common interactive platform for mankind and nature", International Journal of Applied Engineering and Technology, Vol 10,2020,pp:6-14.

[5] Luo C. R., "Uncertainty of Fluvial Ecosystem Its Characteristics, Analysis and Conceptual Management", International Journal of Innovative Application on Social Science and Engineering Technology, Vol. 1, Issue. 1 2020, pp.1-5.

[6] Luo C. R., "Climate change-the cause, influence and conceptual management". International Journal of Applied Engineering and Technology, Vol 10, 2020, pp: 15-25.

[7] Luo C. R., "Water Resources and Waste Water Treatment", International Journal of Innovative Application on Social Science and Engineering Technology, Vol. 2, Issue 1, 2021, pp: $1-8$.

[8] WERC, (2010). "Guidelines for Implementing Seawater and Brackish Water Desalination Facilities". Water Research Foundation, a Consortium for Environmental Education and Technology Development at New Mexico State University.

[9] Willis Gwenzi, George Nyamadzawo. "Hydrological Impacts of Urbanization and Urban Roof Water Harvesting in Waterlimited Catchments: A Review", Environ. Process, November 2014, pp: 573-593. 
ISSN: 2277-3754

ISO 9001:2008 Certified

International Journal of Engineering and Innovative Technology (IJEIT)

Volume 10, Issue 12, June 2021

\section{AUTHOR BIOGRAPHY}

Edward, C. R. Luo was born on 21, March 1957

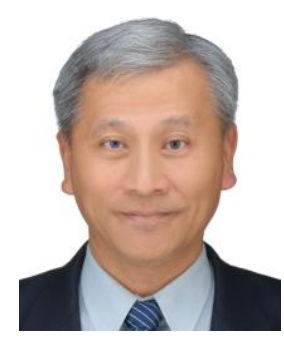

in Taiwan. He has $\mathrm{PhD}$ degree in Business Administration Management, (PALLADIUM University, PALLAMA, and Pacific University, NICARAGUA. 2004-2007) with major in Conflict and Strategic Management; $\mathrm{PhD}$ in Psychology (University of Central Nicaragua, NICARAGUA) with major in Theory and Practice on Psychotherapy and Counselling (2004-2007) and $\mathrm{PhD}$ in Hydrodynamics Engineering (1990 - 1993, Asian Institute of Technology, Thailand) with Major in River, Estuary, Marine, Ecological Engineering, and Debris Flow Engineering.

He has the following professional memberships as follow:2007 to now: Deputy Director General (DDG) of International Biographical Centre (IBC), Cambridge, England;2006 to now: Committee Member on Research and Development of American Biographical Institute (ABI) U.S.A; Certified Licenses: EMF, International Engineers (Hydraulic Engineering); AsiaPacific Engineers (Hydraulic Engineering); Senior Professional Hydraulic Engineer (P.E.), Taiwan; Arbitration Member, Taiwan.

\section{Job Experience:}

Jan. 2010 and continue, Chief Engineer of Hunghua Construction Co., Ltd.

$$
\text { Taichung, Taiwan }
$$

Jan. 2001 and continue, Part-time Assistant Professor of National Chi Nan

$$
\text { University, Nantou, Taiwan. }
$$

Sep.2010 to Aug.2013, Part-time Professor of Palladium University

Sep.2010 to Aug.2013, Part-time Professor of Southern Christian University Sep.2010 to Aug.2013, Part-time Professor of University Central of Nicaragua

July 1997 to 2009, Chief Engineer, Hsing-Nan -Lung Construction

$$
\text { Company }
$$

Jan. 2000 to Dec. 2006, President of Ching-Chan Eng. Ltd

Feb. 1994 to June 1995, Researcher, ITR

March 1984 to Dec. 1986, Advanced Engineer, WRB, MOE.

Aug. 1979 to Feb. 1984, Basic Engineer, WRB, MOE

Books:

MANAGEMENT of SMALL WATERSHED ON the VIEW POINTS of ECOLOGY and ECONOMY, 1993 (In Chinese)

RIVER ENVIRONMENT RESTORATION, 2000 (In Chinese)

RAIN WATER STORAGE and UTILIZATION, 2000 (In Chinese)

\section{Certified Licenses:}

EMF, International Engineers (Hydraulic Engineering)

Asia-Pacific Engineers (Hydraulic Engineering )

Senior Professional Hydraulic Engineer (P.E.), Taiwan

Arbitration Member, Taiwan

Member on Quality Control, Taiwan

Senior Counselor in China, PRC

Senior Health Management Division in China, PRC

Senior Hydraulic Engineer in China, PRC
Senior Architect Engineer in China, PRC

Senior Municipal Utility Engineer in China, PRC

Senior Cost Analysis Engineer in China, PRC 